\title{
An Appraisal of the Effectiveness of the Internet as a Marketing Avenue To Customers in Nigeria
}

\author{
Olasanmi O. O. Agbaje Y. T. \\ Department of Management and Accounting, Obafemi Awolowo University, Ile-Ife
}

\begin{abstract}
The importance of internet marketing has received significant public and corporate attention. However, marketing on the Internet has not received an overwhelming response in Nigeria. The study thus set out to identify the areas of current usage of the internet for marketing, determine the constraints to the effective use of the internet as a marketing platform in Nigeria, and examine how effective internet marketing has been to bank operations. Data for the study were analyzed using both descriptive and inferential statistical tools. The results showed that pricing, customer relations, promotions, and advertising were areas of high significant usage of internet marketing in the banks while constraints to the internet as a marketing platform included high cost of maintenance, information security concerns, and erratic power supply. It was also discovered that the use of internet marketing has effectively reduced staff cost, volume of manual transactions, and number of customers physically attended to. A positive significant relationship was discovered between internet marketing and the customer base of the banks. It was concluded that in spite of some constraints in the use of the internet as a marketing medium, it could also serve as a handy medium to service customer needs.
\end{abstract}

Keywords: Internet, Marketing, Internet Marketing, Customer Base

DOI: $10.7176 /$ RJFA/11-12-07

Publication date:June 30th 2020

\section{INTRODUCTION}

Communication is perhaps man's most important discovery; it pervades virtually all human activities and links up with the environment. Without communication, we are isolated, unable to share thoughts, wishes, needs, wants or feelings with people. Communication may be said to take place when the receiver decodes the message, assesses the damages produced by the impediments during channeling and comprehends the message intended by the source (sender). The quest for man to conquer his environment, time and space has led to numerous technological feats. One of such is the computer, which keeps advancing in leaps and bounds. However, before the advent of the computer, the radio, television, magazines, pamphlets, and billboards have served and still serve as channels of communication. One of the most important aspects of communication is making connections or networking with other people. Marketing encompasses various business activities used to direct the flow of product from the company that makes them to the people who use them. Thus, marketing tends to emphasize on the activities of distribution and transportation of goods and services from where they are produced to where they consumed. However, today, the field of marketing is more than that; it includes the use of the Internet as a medium of marketing. According to Comer (1995), he claims that the Internet is a widely-successful, rapidly-growing, global digital library built on a remarkable flexible communication technology.

Many businesses today uses the Internet as a means of communication, selling products and services over the Internet. One will find a whole lot of products for sales from arts and antiques to stocks and shares. Some companies are not actually selling items over the Internet. Instead, they are using the facilities of the internet to market their products and services, directing one to local sales outlets. Jones (1997) states categorically that "lawyers do business over the internet as do writers, financial advisers and business consultants. So, it's not just products, but services too can be sold over the Internet".

Now that companies and individuals are becoming more interested and begin to appreciate the potentials of the internet, the internet is growing at an unprecedented rate. Let us consider, for instance, the capability to place an order for a pair of shoes, make reservations for flights, bank in cyberspace, browse for automobiles available in the market and make inquiries as to cost, peruse different educational institutions - primary, secondary and tertiary - and make inquiries and reservations by using the internet. The possibilities are unlimited. The users' ability to leverage its benefit for company and personal use is becoming increasingly valuable as the Internet is exposed to more and more people across the world. Thus, the Internet is a medium which could be used to a marketer's advantage or to the advantage of a competitor. However, in Nigeria, in as much as marketers of products and services try to encourage customers to embrace Internet marketing, the response has been very slow and unencouraging.

Establishing a presence in any market place is becoming highly essential to the success of a business. In creating this presence, there is basic information that every organization wants to disseminate. Such as what they have to offer and how prospective customers can contact them. Many businesses in Nigeria today convey such basic information through business cards, brochures, billboards, and posters. Some others use newspapers, 
magazines, radio and television for business promotion. Unfortunately, potential customers in distant geographical locations may not read, hear or see these placements.

In the light of all the above, this study would conducted in a bid to seek the potentials of the Internet as a marketing avenue and whether or not its expectations are being met in terms of attracting potential customers, outsmarting competitors, sharing and distributing information and day-to-day communication to promote goods and services.

\section{OBJECTIVES OF THE STUDY}

The objectives of this study are to:

1) identify the areas of current usage of the internet for marketing;

2) determine the constraints to the effective use of the Internet as a marketing platform in Nigeria; and

3) examine how effective Internet marketing has been to bank operations.

\section{HYPOTHESIS OF THE STUDY}

$\boldsymbol{H}_{\boldsymbol{o}}$ : There is no significant relationship between Internet marketing and the customer base of banks.

\section{LITERATURE REVIEW}

Internet Marketing Concepts

Internet marketing or online marketing has been discovered to be an effective source of improving sales (Duermyer, 2014). It is thus becoming a highly relevant aspect of an organisation's marketing mix, which is composed of price, product, place, promotion and people. For some business owners, it is the only form of marketing being practiced (Duermyer, 2014).

Some key concepts that can offer insight to businesses are:

Mobile marketing: With the proliferation of smart phones and other mobile devices, customers are finding and exchanging information in more channels than before. For business owners, this can mean a range of considerations, taking a look at how you can optimize your website for mobile, to how to use existing mobile messaging platforms or develop your own application.

Location-based marketing: With the rise in mobile marketing, there is also an increase in demand for recognition based on location. Through technology, customers can share where they shop, eat, and other activities - and brands can reward their loyalty. It is a trend that offers small, local businesses like restaurants and retail stores the opportunity to recognize regular customers and offer special promotions.

Connecting online with offline: While some sites connect social networking with physical location, some applications connect social networking to physical objects. Using a smart phone scanner, the sticky bits application can be downloaded and printed, and can be sent to other individuals. In earlier approaches, there were only the product and selling orientations. Recent approaches presently in marketing include relationship marketing with focus on the customer, business (industrial) marketing with focus on an organization or institution, and social marketing with focus on benefits to society. New forms of marketing also use the Internet for marketing, as search engine marketing, desktop advertising or affiliate marketing. It attempts to perfect the inhibitions in traditional marketing. It targets its audience more precisely, and it is sometimes called personalized marketing or one-to-one marketing. Internet marketing is broad in scope, because it not only refers to marketing on the Internet, but also includes marketing done via e-mail and wireless media.

Electronic Commerce (E-Commerce): E-commerce is the process of buying and selling of various products and services by businesses through the Internet. The main focus is to concentrate on business substitutes involving goods and services between various corporations. If an individual runs an e-commerce business, the chances that the customers, regardless of their age, gender or economic status, are active on social networks and social media sharing sites, is high. A business has to discover which social networking channels its customers spend more time on and include them in the e-commerce marketing mix so as not to miss out on building relationships.

With Internet marketing, an individual can go where your customers are, monitor what the competitors are doing, promote exclusive offers through social media, and sell products through social networks. E-commerce could take place at different levels, such as Business to Consumer (B2C), Business to Business (B2B), Consumer to Consumer (C2C), Peer to Peer (P2P), and Mobile Commerce (m-Commerce).

Presently, the Internet might be viewed as a huge market potentially capable of reaching all populations in the whole world. This is why e-commerce is so attractive for many traditional businesses. E-Commerce consists of the buying and selling of products or services over electronic systems such as the Internet and other computer networks. The amount of trade conducted electronically has grown dramatically since the introduction of the Internet. A wide variety of commerce is conducted in this way, including things such as electronic funds transfer, supply chain management, online marketing, online transaction processing, electronic data interchange, automated inventory management systems, and automated data collection systems.

E-commerce market is totally democratic. It is all about marketing and economic rules of demand and supply. 
Many successful purely virtual companies deal with digital products, music, movies, education, communication, software, photography, and financial transactions. Nonetheless, the most recent of the yearly statistics by the International Telecommunications Union (ITU, 2012) indicate that as at year 2012, Nigeria has just 1234 hosts on the Internet, out of the total 1,073,380,925 for the whole of the African Continent. This represents a very small percentage. Some other indicators abound that Nigeria is lagging behind in the utilization of information technology and losing out in terms of the concomitant benefits.

\subsection{Empirical Review of Literature}

The Internet has been thought-out to drastically change the forces at work within the global economy (Selby, 2000; Singh and Kundu, 2002) thus, leading to an appreciable effect on international businesses (de la Torre and Moxon, 2001; Park and Jun, 2003). The explosion of international marketing activity on the Internet has provided a fundamentally different environment for international marketing (Eid and Trueman, 2002; Hitt, Ireland, and Hoskinsson, 2001). Not only has the marketing mix and the adopted marketing strategies been transformed (Strauss and Frost, 2001), the efficiency of traditional marketing functions has also increased. The internet serves as a vehicle that accommodates the process of conducting export business or a tool deployed for promotion, information, and export revenue enhancement (Farhoom and Lovelock, 2001; Palumbo and Herbig, 1998).

A firm can establish its instant presence throughout the world, making direct and immediate entry into foreign markets, via undertaking the activities previously performed by intermediaries (Dunt and Harper, 2002). The Internet, therefore, has the potential to transform and even make obsolete some distribution channels. (Wynne and Berthon, 2001). However, it has also been evidenced that the Internet has added channel intermediaries, rather than displaced them (Williamson, 1999), new intermediaries that help buyers and sellers conduct business are emerging, which is identified as the process of re-intermediation (Klein and Quelch, 1997). These intermediaries provide services in collection, collation, interpretation and dissemination of vast amounts of information, such as directories, advertising, e-payment, insurance, network diagnostics, authentication and certification. This process tends to confirm that, although the middleman can be eliminated from the distribution channel, its functions cannot (Julian and Liesch, 2004).

The Internet allows businesses to communicate widely with actual and potential foreign customers, strategic partners, trading agents, and distributors (Dou, Neilsen, and Tan, 2002). The capability of the Internet in providing interactive, two-way communication plays an important role in the firm's maintenance of long-term relationships (Overby and Min, 2001).

\section{METHODOLOGY}

This study was carried out in South-Western Nigeria, Ibadan, Oyo State. Primary data for the study were collected from respondents using a well-structured questionnaire. Simple random sampling technique was used to select a sample of seven bank-marketing officials from the 23 banks in Ibadan, giving a total of 161 respondents. However, 150 questionnaires were returned, which gives a response rate of 93.2\%. Data from the study were analysed using descriptive and inferential statistics, using Statistical Package for Social Scientists (SPSS). The hypothesis for the study was tested using Analysis of Variance (ANOVA).

\section{RESULTS AND DISCUSSION}

\section{a) Areas of Current Usage of the Internet for Marketing}

From the questionnaires administered to respondents, five major areas of the Internet for marketing usage were identified by the respondents. These areas were promotion, advertising, distribution, pricing, and customer relations. From Table 1, a total of one hundred and seventy-three $(95.3 \%)$ respondents claimed that their use of the Internet for promotion was high while 137 (91.3\%) responded that their use of the internet for advertising was also high out of the 150 respondents sampled for this study. High usage of the Internet respondents for pricing $(92.0 \%)$ and customer relations (98.7\%) were also reported. Moderate usage of the Internet was also reported for distribution purposes $(53.3 \%)$. For the determination of levels of significance, the means of the factors were classified as follows: 4.50 to 5.00 - very high significance; 3.50 to 4.49 - high significance; 2.50 to 3.49 - average significance; 1.50 to 2.49 - low significance; and 0.00 to 1.49 - very low significance. Hence, from the computations in the analyses, it was discovered that pricing and customer relations were areas of very high significance where the Internet was being used by the respondents. Respondents affirmed that prices of different products were readily made available on the Internet for customer information. This serves as an avenue for customers to make appropriate choices on the products they will like to purchase and also make necessary enquiry when needed. It also provides the opportunity to explore products into great details as they may desire. This in turn enhances customer relations, making it easy for customers to build up loyalty to the desired banks. Other areas as suggested by respondents include promotion, advertising and distribution, which were also areas of high significance usage in internet marketing. Various announcements can be publicized to millions of Internet users within a limited period, while giving information on past and present news headlines. Furthermore, banks make 
use of the Internet to advertise vacant positions available to the public. It was acclaimed by the respondents that the Internet avenue made it very easy to share information to the general public at once, whom would have been difficult to reach out to on a one-to-one basis.

Table 1: Areas of current usage of the Internet for marketing

\begin{tabular}{lrrrrr}
\hline Measure & Promotion & Advertising & Distribution & Pricing & Customer Relations \\
\hline Very Low - & 0 & 0 & 0 & 0 & 0 \\
Low - & 0 & 4 & 14 & 4 & 0 \\
Average - 3 & 7 & 9 & 56 & 8 & 2 \\
High - 4 & 74 & 59 & 45 & 43 & 41 \\
Very High - 5 & 69 & 78 & 35 & 95 & 107 \\
Mean Value & 4.41 & 4.41 & 3.67 & 4.53 & 4.70 \\
Standard Deviation & .581 & .724 & .938 & .721 & .488 \\
\hline
\end{tabular}

Source: Field Survey, 2019

\section{b) Constraints to the effective use of the Internet as a marketing platform}

Several constraints to the effective use of the Internet were identified by the respondents. Top among these as depicted on Table 2 were cost of installation, acclaimed by $138(92.0 \%)$ respondents, customers' perception of Internet marketing (136 respondents, 90.7\%) and cost of training (136 respondents, 90.7\%). To determine the level of significance of the measured items, the mean of the constraints were classified as follows: 4.50 to 5.00 - very high significance; 3.50 to 4.49 - high significance; 2.50 to 3.49 - average significance; 1.50 to 2.49 - low significance; and 0.00 to 1.49 - very low significance. From the analysis, since the means of all the constraints fall within the range of 3.50 to 4.49 , it can be rightly deduced that all the constraints, are highly significant constraints that prevent organizations from using the Internet as a marketing platform. The constraints are costs of installing internet facility, information security concern, customers' orientation and perception of the internet, cost of training operators, and cost of maintenance and servicing of the internet facility.

Others are inability to find suitable internet facilities requirement, effect on employees (which include employees' morale, motivation policies, recruitment and retention policies), erratic power supply and the exorbitant cost of running the organization's power plant. It was adjudged by the respondents that the organization was able to operate and maintain internet marketing because it had the funds to meet up with the running costs of operation. This means that, as much as internet marketing is desirable by some organizations, they might not be able to afford the running costs, and hence, might lose out on some global trends and opportunities. It was further suggested that information security was also of concern to the bank officials. Information could easily be copied and used by other individuals to their own benefit. High costs of maintenance are thus involved in mapping out adequate security features and marketing strategies.

Table 2: Constraints to the effective use of the Internet as a marketing platform

\begin{tabular}{|c|c|c|c|c|c|c|c|c|}
\hline Measurement & $\begin{array}{c}\text { Cost of } \\
\text { installati } \\
\text { on }\end{array}$ & $\begin{array}{l}\text { Informati } \\
\text { on } \\
\text { security } \\
\text { concerns }\end{array}$ & $\begin{array}{c}\text { Customer } \\
\text { s' } \\
\text { perceptio } \\
\text { n }\end{array}$ & $\begin{array}{l}\text { Cost } \\
\text { of } \\
\text { trainin } \\
\mathrm{g}\end{array}$ & $\begin{array}{l}\text { Cost of } \\
\text { maintenan } \\
\text { ce }\end{array}$ & $\begin{array}{c}\text { Inabilit } \\
\text { y to } \\
\text { find } \\
\text { suitabl } \\
\text { e } \\
\text { facilitie } \\
\text { s } \\
\end{array}$ & $\begin{array}{l}\text { Effect on } \\
\text { employe } \\
\quad \text { es }\end{array}$ & $\begin{array}{c}\text { Errati } \\
\text { c } \\
\text { powe } \\
\text { r } \\
\text { suppl } \\
y\end{array}$ \\
\hline Very Low - 1 & 0 & 9 & $\overline{0}$ & $\overline{0}$ & 0 & 3 & 0 & 2 \\
\hline Low - 2 & 0 & 2 & 2 & 2 & 0 & 2 & 2 & 13 \\
\hline Average - 3 & 12 & 6 & 12 & 12 & 17 & 12 & 16 & 48 \\
\hline High - 4 & 52 & 39 & 73 & 83 & 72 & 79 & 89 & 43 \\
\hline Very High - 5 & 86 & 94 & 63 & 53 & 61 & 54 & 43 & 44 \\
\hline Mean & 4.49 & 4.38 & 4.31 & 4.23 & 4.29 & 4.19 & 4.15 & 3.76 \\
\hline $\begin{array}{l}\text { Standard } \\
\text { Deviation }\end{array}$ & .642 & 1.060 & .677 & .709 & .661 & .800 & .653 & 1.015 \\
\hline
\end{tabular}

Source: Field Survey, 2019

c) Effective Internet marketing usage on bank operations

From the findings of this study as shown on Table 3, it was discovered that reduced staff cost (148 respondents, 98.7\%), fostering of customers' satisfaction (146 respondents, 97.3\%), and reducing the volume of transactions (143 respondents, 95.3\%) were very highly significant effective areas of internet marketing usage to bank operations in Oyo State, Nigeria. Added to these factors as claimed by other respondents were reduced number of customers physically served (146 respondents, 97.3\%), increased reputation (128 respondents, 85.3\%), and reduced need for branches (116 respondents, $77.3 \%$ ), which were also highly of significant effectiveness to internet marketing. As a result of internet marketing used by banks, information could easily be obtained by customers, 
and hence, there is a reduction in the volume of people that approach the bank for traditional transactions. This leads to an increase in the reputation of such a bank, and make customers more favourably disposed to their operations.

Table 3: Effective Internet marketing usage on bank operations

\begin{tabular}{lrrrrrr}
\hline Measure & $\begin{array}{c}\text { Reduced } \\
\text { number of } \\
\text { customers }\end{array}$ & $\begin{array}{c}\text { Reduced } \\
\text { staff cost }\end{array}$ & $\begin{array}{c}\text { Fosters } \\
\text { customers } \\
\text { satisfaction }\end{array}$ & $\begin{array}{c}\text { Increased } \\
\text { reputation }\end{array}$ & $\begin{array}{c}\text { Reduced } \\
\text { need for } \\
\text { branches }\end{array}$ & $\begin{array}{c}\text { Reduced } \\
\text { volume of } \\
\text { transaction }\end{array}$ \\
\hline Strongly Disagree - & 0 & 0 & 0 & 0 & 2 & 0 \\
Disagree - & 2 & 2 & 0 & 6 & 14 & 2 \\
Neutral - 3 & 2 & 0 & 4 & 16 & 18 & 5 \\
Agree - & 66 & 67 & 46 & 62 & 61 & 42 \\
Strongly Agree - 5 & 80 & 81 & 100 & 66 & 55 & 101 \\
Mean & 4.49 & 4.51 & 4.64 & 4.25 & 4.02 & 4.61 \\
Standard Deviation & .599 & .576 & .534 & .804 & .993 & .622 \\
\hline
\end{tabular}

Source: Field Survey, 2019

\section{HYPOTHESIS TESTING}

Analysis of Variance (ANOVA) was used to test the hypothesis of this study at 5\% level of significance.

Table 4 shows the result of a correlation test for the relationship between internet marketing and customer base. From the result on the table, there is a moderately positive $(0.308)$ correlation between internet marketing and customer base of banks.

Table 4: Correlation between internet marketing and customer base

\begin{tabular}{|c|c|c|c|c|}
\hline Model & $\mathrm{R}$ & R-Square & Adjusted R-Square & $\begin{array}{c}\text { Standard Error of the } \\
\text { Estimate }\end{array}$ \\
\hline 1 & $.308^{\mathrm{a}}$ & .095 & .089 & 3.925 \\
\hline
\end{tabular}

Table 5: Regression test of the relationship between internet marketing and customer base

\begin{tabular}{|c|c|c|c|c|c|c|}
\hline \multirow{2}{*}{\multicolumn{2}{|c|}{ Model }} & \multicolumn{2}{|c|}{ Unstandardized Coefficients } & \multirow{2}{*}{$\begin{array}{c}\text { Standardized } \\
\text { Coefficients }\end{array}$} & \multirow[b]{2}{*}{$\mathrm{t}$} & \multirow[b]{2}{*}{ Sig. } \\
\hline & & $\mathrm{B}$ & Std. Error & & & \\
\hline & (Constant) & \multicolumn{2}{|c|}{27.475} & & 7.064 & .000 \\
\hline & Internet marketing & \multicolumn{2}{|c|}{.698} & .308 & 3.936 & .000 \\
\hline
\end{tabular}

a. Dependent Variable: Customer base

The value from the $F$-distribution table (i.e. $\left.F^{T}\right)$ at $5 \%$ level of significance, at the degrees of freedom $(1$ and 148 ) is 3.84. The result of the ANOVA test is as shown on the Table 6.

Table 6: ANOVA test of the relationship between internet marketing and customer base

\begin{tabular}{llrrrrr}
\hline Model & & Sum of Squares & Df & Mean Square & F & Sig. \\
\hline & Regression & 238.773 & 1 & 238.773 & 15.495 & $.000^{\mathrm{a}}$ \\
& Residual & 2280.561 & 148 & 15.409 & & \\
& Total & 2519.333 & 149 & & & \\
\hline
\end{tabular}

a. Predictors: (Constant), Internet marketing

b. Dependent Variable: Customer base

Since the ANOVA calculated value (15.495) is greater than the table $(F)^{T}$ value $(3.84)$, we reject the null hypothesis at the $5 \%$ level of significance and conclude that there is a positive significant relationship between internet marketing and the customer base of banks. This means that the more industries make use of the internet for marketing, the more the number of customers they will have. 


\section{CONCLUSION}

This study was conducted to appraise the effectiveness of the internet as a marketing avenue on customers in Nigeria. In other to achieve this, the study aimed to identify the areas of current usage of the internet for marketing; determine the constraints to the effective use of the Internet as a marketing platform in Nigeria; and examine how effective Internet marketing has been to bank operations.

It was discovered that organizations and banks are increasingly using the internet to enhance customer relations, display pricing activities, offer promotion, advertising, and distribution activities. Furthermore, it was also discovered present usage of the internet by organizations was not at its maximum due to some constraints such as cost of installation, information security concerns, customers' perception of the internet, cost of maintenance, and erratic power supply. The results from the study also showed that internet marketing has helped banks to foster customer satisfaction, reduced the volume of physical transactions, reduced the number of customers physically served, and reduced the need for several branches. There was also a positive significant relationship between internet marketing and the customer base of banks.

It can thus be concluded that internet marketing should be embraced by more organizations since it can lead to increased customer base, if the constraints to its usage are adequately care of.

\section{RECOMMENDATIONS}

1. Organizations and banks should use the internet in their operations as its usage guarantees increased customer patronage among other positive benefits.

2. Government should put in place adequate policies such as internet infrastructure and the provision stable power supply so that some constraints prohibiting the usage of internet marketing can be addressed.

\section{REFERENCES}

Ayaz, M. (2017) The Five Different Types of E-Commerce, http://www.designzzz.com/, Accessed on 11/08/2019. Benjamin R. and Wigland, R. (1995) Electronic Markets and Virtual Chains On The Information Superhighway", Sloan Management Review, Vol. 36, No. 2, pp. 62-72.

Bennett, R. (2008) Using the worldwide web for international marketing: Internet use and perceptions of export barriers among German and British businesses, Journal of Marketing Communications, Vol. 4, No. 1, pp. $27-43$.

Bowles, M. (2018) 5 Social Media Tips for Ecommerce Marketing, Top Rank Online Marketing, www.toprankmarketing.com, Accessed on 12/01/2019.

Brock, J.K. (2001)@Market space and the new mechanism of internationalisation: Some preliminary insights" in Taggart, J. H., Berry, M. and McDermott, M. (eds.), Multinationals in a New Era: International Strategy and Management, Palgrave, New York, pp. 88-104.

Chaffey D., R. Mayer, K. Johnston and F. Ellis-Chadwick (2017) Internet Marketing: Strategy, Implementation and Practice, FT Management, http://www.marketing-online.co.uk/, Accessed on 15/08/2019.

de la Torre, J. and Moxon, R.W. (2001) Introduction of the symposium e-commerce and global business: the impact of the information and communication technology revolution on the conduct of international business, Journal of International Business Studies, Vol. 32, No. 4, pp. 617-639.

Dou, W., Neilsen, U.O. and Tan, C.M. (2002) Using corporate websites for export marketing, Journal of Advertising Research, Vol. 42, No. 5, pp. 105-115.

Duermyer R. (2018) What is Internet Marketing and How Can Online Marketing Work for Me? http://homebusiness.about.com/od/marketingadvertising/a/IMarketing101.htm, Accessed on 04/08/2019.

Dunt, E.S. and Harper, I. R. (2002) E-Commerce and the Australian economy, The Economic Record, Vol. 78, No. 242 , pp. 327-342.

Dynamic Business (2018) 7 Strategies for customer loyalty in the digital age, Dynamic Business Magazine, http://www.dynamicbusiness.com.au/sales-and-marketing/, Accessed on 15/092019.

Eid, R. and Trueman, M. (2002) The Internet: new international marketing issues, Management Research News, Vol. 25, No. 12, pp. 54-67.

Ewah O.E. and A.B. Ekeng (2009) Problems and Prospects of Marketing in Developing Economies: The Nigerian Experience, International Journal of Business and Management, Vol. 2, No. 15.

Farhoom and, A. and Lovelock, P. (2017) Global E-Commerce: Texts and Cases, Prentice- Hall, Singapore.

Fisher, M. and Reibstein, D.J. (2001) "Technology-Driven Demand: Implications for the Supply Chain" in Wind, J. and Mahajan, V. (eds.), Digital Marketing: Global Strategies from the orld's Leading Experts, Wiley, New York, pp. 285-309.

Gordon, M.E. and de Lima-Turner, K. (1997) Consumer attitudes towards Internet advertising: a social contract perspective, International Marketing Review, vol. 14, no. 5, pp. 362-375.

Hamill, J. (1997) The Internet and international marketing, International Marketing Review, vol. 14, no. 5, pp. 300-323. 
Hitt, M.A., Ireland, D.R. and Hoskinsson, R.E. (2001), Strategic Management: Competitiveness and Globalization, 4th ed., South-Western College Publishing, Ohio.

Hoffman, D.L. and Novak, T.P. (1996) Marketing in hypermedia computer-mediated environments: conceptual foundations, Journal of Marketing, vol. 60, no. 3, pp. 50-68.

Internet World Statistics (2017) Usage and Population Statistics, http://www.internetworldstats.com/stats1.htm, Accessed on 19/08/2019.

Johanson, J. and Vahlne, J. (1990), “The mechanism of internationalisation", International Marketing Review, vol. 7, no. 4, pp. 11-24.

Jones, G.I. (2017), Doing Business on the Internet, How to Books Ltd., Plymouth.

Julian, C.C. and Liesch, P. (2004), The impact of the Internet on Australian Firms Export Marketing Performance, The Australian and New Zealand International Business Academy (ANZIBA) Annual Meeting, Canberra, Australia.

Khan, R.E. (2011), Developing the theoretical and conceptual framework, J199 Lecture.

Kotler, P. (2016), Marketing management-Analysis, Planning, Implementation and Control, $8^{\text {th }}$ Edition, PrenticeHall International, New Jersey.

Levine, J.R., C. Barondi and M.L. Young (2007), The Internet for Dummies, $7^{\text {th }}$ Edition, IbG Books Worldwide Inc., Canada.

McCarthy, J. (1987), Generality in Artificial Intelligence, in "Communications of the ACM", Vol. 30, No. 12, pp. 1030-1035. Also in "ACM Turing Award Lectures, The First Twenty Years", ACM Press, 1987.

Melville-Ross, T. (1998), The changing face of business, in Nash, T. (Ed.) "Electronic commerce: directors and opportunities for electronic Business", Director Publications Ltd., London.

O'Keefe, R.M., O'Connor, G. and Kung, H. (1998), "Early adopters of the web as a retail medium: small company winners and losers", European Journal of Marketing, vol. 32, no. 7/8, pp. 629-643.

Overby, J.W. and Min, S. (2001), "International supply chain management in an Internet environment: a networkoriented approach to internationalisation”, International Marketing Review, vol. 18, no. 4, pp. 392-420.

Oxford University Press (2002), Oxford Dictionary of Business, Market House Books Ltd., United Kingdom.

Palumbo, F. and Herbig, P. (1998), "International marketing tool: the Internet", Industrial Management and Data Systems, vol. 98, no. 6, pp. 253-261.

Park, C. and Jun, J. (2003), "A cross-cultural comparison of Internet buying behaviour: effect of Internet usage, perceived risks, and innovativeness", International Marketing Review, vol. 20, no. 5, pp. 534-553.

Prashantham, S. (2003), “The Internet and international marketing”, The Marketing Review, vol. 3, no. 4, pp. 403418.

Quelch, J.A. and Klein, L.R. (1996), "The Internet and international marketing”, Sloan Management Review, vol. 37, no. 3, pp. 60-75.

Ramshaw, A. (2017), Practical Strategies for retaining your customers, http://integrati.com.au/loyalty/practicalstrategies-for-retaining-your-customers/, Accessed on 15/08/2019.

Reilly, M.A. (2017), 4 Key Trends for Marketing in Real-Time, American Express Company, http://www.openforum.com/idea-hub/topics/marketing/article/, Accessed on 11/01/2019.

Riddle, D. (1999), "Using the Internet for service exporting: tips for service firms", International Trade Forum, vol. 1, pp. 19-23.

Samiee, S. (1998), "Exporting and the Internet: a conceptual perspective", International Marketing Review, vol. 15 , no. 5, pp. 413-426.

Schlegelmilch, B.B. and Sinkovics, R. (1998), "Viewpoint: marketing in the information age - can we plan for an unpredictable future"? International Marketing Review, vol. 15, no. 3, pp. 162-170.

Schramm, W. (1971), How Communication Works, in 'Communication: Concepts and Process', Derito, J.A., Prentice-Hall Inc., New Jersey.

Selby, J. (2000), “Adding value in the digital economy: Australia's TPO experience”, International Trade Forum, vol. 4 , pp. 29-30.

Singh, N. and Kundu, S. (2002), "Explaining the growth of e-commerce corporations (ECCs): an extension and application of the eclectic paradigm", Journal of International Business Studies, vol. 33, no. 4, pp. 679-697.

Step-by-step marketing (2009), 5 powerful secrets to retaining customers, http://www.stepbystepmarketing.com/daily/customer_retention_strategy/, Accessed on 11/08/2019.

Strauss, J. and Frost, A. (2016), E-Marketing, Prentice-Hall, New Jersey.

Tawose, S.A. (2005), Computer Appreciation, Mathsvillage and Matrix Investment, Obafemi Awolowo University, Ile - Ife.

Wynne, C. and Berthon, P. (2001), "The impact of the Internet on the distribution value chain: the case of the South African tourism industry", International Marketing Review, vol. 18, no. 4, pp. 420-431. 